\title{
Conceptualizing legal culture and legal awareness: meaning and structural components
}

\author{
Madina Kozhukhova ${ }^{1, *}$, and Miras Zhiyenbayev ${ }^{1}$ \\ ${ }^{1}$ Karaganda State Technical University, 100027, 56 Mira ave., Karaganda, Kazakhstan.
}

\begin{abstract}
The paper discusses the meaning and structural components of such concepts as legal culture and legal awareness. The authors review main approaches to defining these two concepts, outline their characteristics and distinctive features. It is emphasized that the phenomena have specific features in transit societies, in which the sense of justice is of particular importance since it, in many respects, ensures the legal order and evolutionary character of social transformations. In addition, the paper focuses on the interrelation of legal culture and legal awareness.
\end{abstract}

\section{Introduction}

Legal culture is a special layer of culture that can be associated with the society as a whole, political and legal state bodies, officials, social groups, ordinary citizens, etc. It is believed that the legal culture is closely connected with legal awareness and even relies on it. Some also believe that the concept of legal culture is broader than the concept of legal awareness, because the first one includes not only certain ideological and psychological elements, but also the legally meaningful behavior of citizens.

The paper critically reviews the existing concepts of legal culture and legal awareness, emphasizing their fundamental roles in the transition societies, focusing on Kazakhstan and other post-Soviet countries.

\section{Understanding the concept of legal culture: main approaches}

Several constituent parts can be distinguished in the legal culture, namely material, information, and subjective ones $[1,2,3]$. The material part of the legal culture forms the basis for the functioning of other parts of culture in the form of state and legal organizations, institutions, finance, technological support of social and legal relations, and so on. The information part of the legal culture includes the accumulation of aggregate legal information in the historical, factual, and logical aspects. In addition, it provides accumulation, storage, processing, and translation of legal information in the society, which in general creates an information basis for legal relations. The subjective part of the legal culture is its anthropological component, organically connected with the legal

\footnotetext{
* Corresponding author: k_madina78@mail.ru
} 
consciousness of the subjects $[4,6,7,8]$. It provides the opportunity and the need for a person, a group of people, and a population of a particular society to master the foundations and norms of legal culture, as well as legal behavior in society. More than that, the subjective part of the legal culture is fixed in the sense of justice and is realized on the basis of the latter in many acts of people. The most holistic, by definition, should be the legal awareness of professionals who have a professional legal education. These are the specialists, legal theorists and practicing lawyers, who are obliged to master the norms of legal culture in the most profound way, have the highest level of legal awareness, and are able to implement this in competent law enforcement.

To present the full essence of the legal culture that is being formed in the process of legal education, it is necessary to distinguish its logical structure. In this plane, the legal culture represents legal concepts and categories, evaluations (evaluative judgments), and deontological legal modalities. Legal concepts and categories constitute the rational side of the legal culture of the individual and express the degree of knowledge and understanding of legal phenomena that she/he has achieved. Legal concepts can serve as the basis for the formation of the evaluation aspect of the legal culture of the individual. Normative judgments are formed in legal education on the basis of legal knowledge, assessments and promote self-regulation of the individuals' legal behavior of the individual. It is associated with the development of the critical function of consciousness, therefore it is an integral part of a specialist's legal awareness. Critical professional approach to the legal phenomena of society not only allows us to understand the role of legal culture as a factor ensuring the maintenance of progressive legal norms, but also contributes to the abolition of obsolete regulators, the formation of new legal social levers for the improvement of society, corresponding to a high technical, legal, ideological, and theoretical level.

The question of the structure of legal culture in modern philosophical and legal literature is debatable. For instance, Salnikov believes that the structural elements of legal culture are the components of legal activity in their particular perspective of the standards of behavior: law, legal conscience, legal relations, law and order, lawful activity of subjects. As for its content, it includes not just legal awareness, legality, etc., but also the character, level, degree of their development, that is, what gives them this stage of civilization and social progress [6].

The structure of the subject part of the legal culture can be divided into the following main elements: (a) psychological (legal psychology in vocational education); (b) ideological (legal ideology in education); and (c) behavioral (legally significant behavior as an applied result of education).

However, we note that, according to Semitko, the separation of structural elements of legal culture is rather arbitrary, since there is no legal activity carried out separately from the legal awareness, legal awareness can appear only in legal activity and its results, that is, in legal acts [7].

Karipbaev believes that the elements (subsystems) of legal culture are the level states, i.e. the "degree of legal development" of such components of the legal system of society as: (a) legal texts (documents and texts having legal content); (b) legal activities (theoretical and practical); (c) legal awareness (including cognitive, emotional, and installation components); (d) the subject as the bearer of legal culture (society, classes, nations, nationalities, collectives, and individuals) [8].

Other authors include cultural complexes in the legal culture: lawmaking, legal science, law, legal relations, criteria for political evaluation of law and legal behavior, legal awareness, and legal institutions. In terms of importance, some researchers suggest a number of levels in the structure of legal culture: (a) the first level is related to legal needs, subconscious structures of legal culture (attitudes, interests, inclinations, desires, feelings, etc.); (b) the second level means the availability of legal knowledge and the ability to use 
them; (c) the third level implies the "formalized" attitude to the law; and (d) the fourth level is behavior and activity in situations that have legal content.

The degree of organic nature of the proposed structure undoubtedly affects the quality of legal knowledge and the ability to use them, on the nature of the attitude to the law (respect for it, the sense of legality), as well on the willingness to comply with legal norms and to promote the strengthening of law and order. It should be noted that in professional legal education all the aforementioned levels should be presented as they are mastered and complicated in mastering the specialty. The legal culture functions in interaction with other areas or spheres of culture: political, moral (ethical), aesthetic, religious, etc. Moreover, in the specific content of the legal culture, features and peculiarities that are characteristic of both the prevailing culture of a given society and its individual areas are necessarily manifested.

Depending on the bearer of legal culture, one can distinguish the legal culture of society and the legal culture of the individual. Here the common is expressed in the aggregate of individual consciousness and cultures of people, which are purposefully formed in the process of legal education. The organizing core in this case is a philosophical, legal, and professional legal education.

The essence of the legal culture of the individual can be expressed by the following formula: know - respect - follow. The authors have in mind the requirements of the laws. As in the case with legal awareness, this is the primary, ordinary level of legal culture, which, however, acquires a social significance. Legal culture of the individual should be considered separately from the legal culture of individual social groups and society as a whole (which is reflected in the relevant vocational education disciplines). The legal culture of a group is characterized by the level of legal awareness of this social group, as well as the level of compliance with law. A group feels the influence of the value orientations that prevail in society and the influence of individual personalities who give this or that character to these orientations.

The legal culture of society is an integral part of the values that it created. It includes such "indicators" as the achieved level of legal consciousness, full-fledged legislation, a developed legal system, effective independent justice, a wide range of rights and freedoms of a citizen and their guarantees, the state of law and order, strong legal traditions, the legal literacy of the population, the clear work of law enforcement agencies, respect for laws, and much more, which all together determine the legal life and legal development of the state.

\section{The concept of legal awareness: key characteristics}

Recognizing the law as objective social reality, we must recognize the existence of a subjective reaction of people to law, i.e. the legal awareness of citizens. Legal awareness is the inevitable companion of law $[8,9]$. This is due to the fact that law is the regulator of relations between people endowed with will and consciousness. It is quite obvious that the process of creating law (law-making) is connected with the conscious activity of people, and the law itself is the product of this activity. It is also clear that the process of the implementation of law is usually a conscious, volitional activity of people. Therefore, such phenomena as law, legal culture, legal consciousness, professional legal education, general legal education and education, legal behavior of the population, and its individual citizens (professional lawyers and non-professionals) are inherently connected. The legal awareness is a combination of ideas and feelings that express the attitude of people towards law and legal phenomena in public life. It usually does not exist in a "pure" form, it is interconnected with other types and forms of awareness of reality. So, often, legal awareness is intertwined with moral views. People assess the law and legal phenomena 
from the standpoint of moral categories of good and evil, justice and injustice, conscience, honor, etc. Attitude to law is also often determined by political views.

The influence of legal awareness, and with it of legal education, on the organization of public life is quite large. The most visible role is played by legal awareness in the process of the implementation of legal rights and obligations. Human life clearly demonstrates that consciousness, thought, image, and volitional efforts really control the behavior of people, initiate and regulate their actions and actions in all spheres of life, including legal.

The level, quality, character, content of professional legal education, as well as general legal education and citizens' education determine what will be legal awareness and the behavior of people in society. Whether it will be lawful, socially useful, unlawful, or socially harmful and dangerous.

The concept of legal awareness (both individual and collective) is a complex structural formation, in which it is possible to identify rational components usually being called a legal ideology. Within this concept, one can also distinguish the emotional and sensual structural elements that are embraced by legal psychology. Therefore, legal education includes knowledge of legal awareness as a complex structured phenomenon. Any trainee should receive not only theoretical knowledge, but also necessary skills in order to be able to apply this knowledge in practice.

In real life, legal awareness manifests itself as a whole, unstructured. The isolation of structural elements in legal awareness contributes only to an understanding of its role and place in the life of an individual and society as a whole. As you know, legal awareness can be divided into three levels. The first level is everyday legal awareness. It is typical for a wide strata of the population of a particular society. The general legal culture, social calmness, the way of creating social life largely depends on his condition. The second level is the professional legal awareness, which is formed in the process of legal education and practice. The subjects of this level have specialized, detailed knowledge of the current legislation and skills of its application. The formation of a professional legal awareness should be given special attention in modern conditions. The third level is scientific, theoretical legal awareness. It is characteristic for researchers engaged in issues of legal culture, the philosophy of law, rulemaking, and conceptual foundations of the legal regulation of social relations. Humanitarian researchers are working here.

With respect to subjects, legal awareness can be divided into individual and collective. Group legal awareness is one of the types of collective legal awareness, which should be distinguished from the mass one (typical for unstable, temporary associations of people). To characterize macro-collectives (population of the country, continent, historical era), one uses the notion of "public sense of justice." The legal views of nations and nationalities can also be assigned to this category. To characterize a macro group of people (population of the country, continent, historical era), one uses the notion of "public legal awareness." Certain legal views of nations and nationalities can also be assigned to this category.

\section{Legal awareness and legal culture}

An analysis of the attitude of people to laws and other normative legal acts makes it possible to identify other elements in legal awareness that determine its relationship with the legal culture.

The first element is informational. It is the presence in the mind of certain information about the law. Information can be complete and comprehensive (for example, after working with a text on law, acquaintance with the process of its adoption, reading comments on this law) and may be superficial, with someone else's words. The information level of legal awareness is its obligatory structural part, there can be no relation to the law without proper information about it. 
The second element is evaluative. Having received information about a normative act, a person somehow relates to it, assesses it, compares it with its own values. Axiological (value) elements of legal awareness occupy an important place in its structure. Based on the value representations of a person, the motives for his/her behavior in the legal sphere are being formed. Awareness of the value of the right by a person facilitates the transformation of the right from being "alien", emanating from external forces, from power social structures, into becoming "one's own" and contributing to the realization of the goals and interests of peoples.

On the basis of information and evaluation elements, the third element is formed, which is volitional one. After learning about the law and assessing it, a person decides what he/she will do in the conditions prescribed by law. Whether to use the law to benefit yourself or just "bypass" it, to strictly follow this law or find other legal acts more in line with interests and needs. All these moments are part of the volitional element of legal awareness. The volitional focus of legal awareness is sometimes referred to as a legal setting, i.e. a psychological direction and willingness of a person to somehow act in the sphere of legal regulation.

\section{Conclusion}

The legal culture underlying legal awareness, in a broad sense, can be regarded as a reality in all the diversity of its material and spiritual manifestations. The legal culture of a society is a part of the social culture that has been formed in this society at a certain stage of its development. It characterizes the qualitative state of the legal life of society [9].

Analysis of the legal culture and its formation in legal education is necessary in order to, first of all, identify and describe the legal values, ideals, and patterns that are mastered by a professional lawyer and to which legislators, law enforcement officials, citizen, and society as a whole should strive. Only then a specialist, evaluating from this point of view the real state of affairs, is able to look for ways and means to achieve the ideals in the construction of the rule of law and society, where not only the human rights and freedoms that are relevant to its socio-economic and spiritual order are ensured, but there is also an adequate level of responsibility of individuals for their actions within the framework of the constitution and legal culture.

Legal culture is inconceivable without a person and his activity, determined by the worldview, without the progressive orientation of this activity and this thinking. It acts as a social phenomenon with a clearly defined target orientation. The legal culture of the society is the guarantor of the legal protection and civic activity of the individual, "forces" the power to give legal status to a person of legal significance.

It acts as a social phenomenon with a clearly defined target orientation. The legal culture of the society is the guarantor of the legal protection and civic activity of the individual, "forces" the government to give legal significance to a legal status to a person. Undoubtedly, this subjective part of the legal culture is purposefully formed in the process of professional legal education of professional lawyers, which make up the content core of this part of the legal culture. But, in addition, broad legal education of the population is also necessary. It should be initiated by specialists in the field of general humanities (philosophers, sociologists, political scientists, and educators) as well as professional lawyers.

Legal culture is mastered in the process of a person's life, becoming fixed in his/her legal awareness. Therefore, it should be developed in the process of legal education of the population: in the family, labor and other collectives of people, through public media, in the process of joint legal actions of citizens, etc. 


\section{References}

1. Ya. V. Zubova, Bulletin of the Adyghe State University - Series 1: Regional Studies: Philosophy, History, Sociology, Jurisprudence, Political Science, Culturology, 2 (2009)

2. S. S. Alekseev, Theory of state and law (Norma, Moscow, 2004)

3. T. S. Kosenko, Philosophy of Education, 4, 21 (2008)

4. V. P. Dik, Philosophy of Education, 1 (2007)

5. Kh. P. Pashaev, Philosophy of Education, 1 (2007)

6. S. A. Komarov, General theory of state and law (Yurayt, Moscow, 1997)

7. A. P. Semitko, Development of legal culture as legal progress (Ural State Law University, Yekaterinburg, 1996)

8. B. I. Karipbaev, Sociocultural and cognitive foundations of law (Almaty, 2008)

9. M. T. Baimakhanov, L. M. Vaisberg, Interaction of legal consciousness with morality and morality in a society of a transition period (Zheti Zhargy, Almaty, 1995) 